\title{
Sistem Pakar Penyakit Tanaman Kopi (Coffea Sp)Metode Forward Chaining Berbasis Web
}

\author{
Mohammad Denny Gunawan \\ Politeknik Pertanian Negeri \\ Samarinda \\ Teknologi Rekayasa Perangkat \\ Lunak, \\ Manajemen Pertanian \\ Samarinda,Indonesia \\ denny.gun23@gmail.com
}

\author{
Annafi' Franz \\ Politeknik Pertanian Negeri \\ Samarinda \\ Teknologi Rekayasa Perangkat \\ Lunak, \\ Manajemen Pertanian \\ Samarinda, Indonesia \\ annafifranz@gmail.com
}

\author{
Riama Rita Manullang \\ Politeknik Pertanian Negeri \\ Samarinda \\ Budidaya Tanaman Perkebunan, \\ Manajemen Pertanian \\ Samarinda, Indonesia \\ rita@politanismarinda.ac.id
}

\begin{abstract}
Abstrak - Kopi merupakan komoditas ekspor penting bagi Indonesia yang mampu menyumbang devisa yang cukup besar. Penelitian ini dilatarbelakangi oleh Kurangnya informasi yang diketahui oleh pihak perkebunan kopi tentang jenis penyakit yang tanaman kopi yang tidak tertangani dengan benar. Oleh Karena itu tujuan dari penelitian ini adalah Tujuan dalam tugas akhir ini adalah merancang dan membuat aplikasi sistem yang dapat digunakan untuk mendeteksi penyakit pada tanaman kopi. Merancang suatu sistem pakar berbasis web yang dapat dimengerti dengan mudah oleh petani. Hasil Penelitian Aplikasi ini dapat memudahkan petani untuk mengetahui gejala dan penyakit pada tanaman kopi. Forward Chaining dapat dijadikan alternatif dalam melakukan hasil terhadap penentuan gejala dan penyakit tanaman kopi.
\end{abstract}

Kata Kunci-tanaman kopi, sistem pakar, forward chaining

\section{Pendahuluan}

Perkembangan dunia teknologi informasi saat ini telah mempengaruhi segala aspek kehidupan manusia, bahkan di dalam bidang-bidang di luar disiplin ilmu komputer. Salah satu cabang ilmu komputer yang dapat membantu manusia adalah system pakar Expert System. Tujuan praktis dari system pakar ini adalah membuat computer semakin berguna bagi manusia. Sistem pakar dapat membantu manusia dalam membuat keputusan, mencari informasi atau solusi yang lebih akurat. Sistem pakar juga dapat diterapkan di bidang perkebunan.

Tanaman kopi termasuk dalam genus coffea dengan family Rubiaceae. Family tersebut memiliki banyak genus, yaitu Gardenia, Ixora, Cinchona, dan Rubia. Genus Coffea mencakup hampir 70 spesies, tetapi hanya ada dua spesies yang ditanam dalam skala luas diseluruh dunia, yaitu kopi arabika (Coffea arabica) dan kopi robusta (Coffea canephoravar. robusta). Saat ini, sebagian besar tanaman kopi dibudidayakan di Indonesia adalah kopi robusta 90\% dan sisanya kopi arabika.

Kopi merupakan komoditas ekspor penting bagi Indonesia yang mampu menyumbang devisa yang cukup besar. Pada tahun 2010 luas areal kebun kopi mencapai 1.210.365 ha dengan produksi 686,92 ton dan volume ekspor 433.595 ton atau setara dengan US\$ 814.311.000. Komposisi kepemilikan perkebunan kopi di Indonesia didominasi oleh Perkebunan Rakyat (PR) dengan porsi 96\% dari total areal di Indonesia, dan yang 2\% sisanya merupakan Perkebunan Besar Negara (PBN) serta 2\% lainnya merupakan Perkebunan Besar Swasta (PBS).

Kurangnya informasi yang diketahui oleh pihak perkebunan kopi tentang jenis penyakit yang tanaman kopi yang tidak tertangani dengan benar. Hal ini mengakibatkan banyak tanaman kopi yang seharusnya bisa terselamatkan menjadi mati dan kualitas kopi tersebut menurun. Jika hal ini dibiarkan terus-menerus, maka akan berimbas pada tingkat produktivitas tanaman kopi tersebut. Timbul masalah bagaimana supaya pihak perkebunan kopi dapat mengetahui jenis penyakit yang menyerang tanaman kopi dan mengambil tindakan yang tepat untuk menangani tanaman kopi yang terserang penyakit tanpa adanya seorang ahli.

Berdasarkan permasalahan di atas, pihak perkebunan kopi membutuhkan sebuah alat bantu yang dapat memberikan informasi mengenai penyakit yang menyerang tanaman kopi dan memberikan solusi untuk menangani penyakit tersebut. Alat bantu tersebut dapat berupa sebuah aplikasi sistem pakar, dengan tujuan, aplikasi system pakar ini dapat membantu pihak perkebunan kopi untuk mengetahui jenis penyakit yang sedang menyerang tanaman kopi berdasarkan pada gejala-gejala penyakit yang terlihat dan juga dengan adanya aplikasi system pakar ini, dapat membantu memberikan solusi untuk menangani tanaman kopi yang terserang penyakit, sehingga banyak tanaman kopi yang dapat diselamatkan dari gangguan penyakit.

Kesimpulan yang dihasilkan merupakan hasil penelusuran dari seperangkat data atau fakta yang berupa gejala penyakit pada tanaman kopi. Untuk itu, metode yang dapat digunakan adalah metode forward chaining yang merupakan suatu metode dari inference engine untuk memulai penalaran atau pelacakan suatu data dari fakta-fakta yang ada menuju suatu kesimpulan (Dologite, 1993). Dari fakta-fakta yang berupa gejala penyakit pada tanaman kopi tersebut akan diolah untuk mendapatkan 
sebuah kesimpulan berupa hasil diagnosis penyakit yang menyerang tanaman kopi dan membantu memberikan solusi untuk melakukan tindakan pengendalian yang tepat. Kesimpulan yang dihasilkan akan digunakan sebagai pendukung keputusan bagi pihak perkebunan kopi untuk mengambil tindakan dalam menangani tanaman kopi yang terserang penyakit.

Alasan Memilih metode forward chaining karena terdapat banyak cara atau aturan yang berbeda untuk mendapatkan kesimpulan yang sedikit, dan ingin mendapatkan kesimpulan dari fakta-fakta yang sudah ada sebelumnya.

Berdasarkan latar belakang di atas, maka didapatkan rumusan masalah yaitu, Bagaimana merancang suatu sistem pakar berbasis web untuk mendiagnosis penyakit tanaman pada kopi sesuai pengetahuan pakar.

\section{TINJAUAN PUSTAKA}

\section{A. Studi Literatur}

Penelitian yang dilakukan oleh Maruapey (2017) yang berjudul Sistem pakar diagnosis hama tanaman kopi Berbasis web. Dalam mengatasi hal tersebut, salah satu solusinya adalah memberikan edukasi kepada petani kopi tentang hama dan penyakit kopi melalui pakar atau ahli tanaman kopi dari pusat penelitian, akademisi, serta petugas penyuluh pertanian (PPL). Minimnya pakar atau ahli pertanian yang memberikan edukasi bagi petani kopi, menyebabkan para petani tidak memiliki pengetahuan yang cukup tentang budidaya kopi dan hama tanaman kopi. Ini mempengaruhi produktifitas kopi karena para petani tidak mengetahui solusi penanggulangan. Sistem pakar ini dapat membantu memberikan rekomendasi solusi untuk menanggulangi masalah para petani Indonesia khususnya pada masalah hama tanaman kopi. Perbandingan dengan penelitian terdahulu dapat dilihat pada table 1 :

Tabel 1. Perbandingan Peneliti Terkait

\begin{tabular}{|l|l|l|}
\hline $\begin{array}{l}\text { Nama } \\
\text { Peneliti }\end{array}$ & Judul & $\begin{array}{l}\text { Perbedaan } \\
\text { Penelitian } \\
\text { Sebelumnya }\end{array}$ \\
\hline $\begin{array}{l}\text { Defitri } \\
2012\end{array}$ & $\begin{array}{l}\text { Sistem Pakar } \\
\text { penyakit tanaman } \\
\text { kopi (Coffea } \text { sp) } \\
\text { di desa mekar } \\
\text { jaya Jabung Barat }\end{array}$ & $\begin{array}{l}\text { Sistem ini } \\
\text { Metode forward } \\
\text { chaining } \\
\text { penelitian ini } \\
\text { meggunakan } \\
\text { bahasa PHP dan } \\
\text { databasenya } \\
\text { menggunakan } \\
\text { MYSQL. }\end{array}$ \\
& & \\
\hline
\end{tabular}

\begin{tabular}{|c|c|c|}
\hline $\begin{array}{l}\text { Angkie dkk } \\
2010\end{array}$ & $\begin{array}{l}\text { Aplikasi Sistem } \\
\text { Pakar } \\
\text { Untuk } \\
\text { Mendiagnosis } \\
\text { Penyakit pada } \\
\text { Tanaman Kopi } \\
\text { dengan Metode } \\
\text { Forward Chaining }\end{array}$ & $\begin{array}{l}\text { Sistem Pakar } \\
\text { menggunakan } \\
\text { bahasa } \\
\text { pemrograman } \\
\text { Visual Basic } \\
\text { 2008 dengan } \\
\text { Databasenya } \\
\text { menggunakan } \\
\text { MYSQL. }\end{array}$ \\
\hline $\begin{array}{l}\text { Apriansyah } \\
2016\end{array}$ & $\begin{array}{l}\text { Sistem Pakar } \\
\text { Pengendalian } \\
\text { hama dan } \\
\text { penyakit pada } \\
\text { budidaya tanaman } \\
\text { kopi berbasis web }\end{array}$ & $\begin{array}{l}\text { Bahasa yang } \\
\text { digunakan yaitu } \\
\text { PHP dan } \\
\text { MYSQL }\end{array}$ \\
\hline $\begin{array}{l}\text { Maruapey } \\
2017\end{array}$ & $\begin{array}{l}\text { Sistem pakar } \\
\text { diagnosis hama } \\
\text { tanaman kopi } \\
\text { Berbasis web }\end{array}$ & $\begin{array}{l}\text { Sistem ini } \\
\text { menggunakan } \\
\text { bahasa PHP dan } \\
\text { MYSQL. }\end{array}$ \\
\hline
\end{tabular}

\section{B. Kecerdasan Buatan}

Kecerdasan buatan (Artifitical Intelligence) adalah "ide-ide untuk membuat suatu perangkat lunak suatu komputer yang memiliki kecerdasan sehingga perangkat lunak komputer tersebut dapat melakukan pekerjaan yang dilakukan oleh manusia" (Turban, 2004), dengan kata lain membuat sebuah komputer dapat berpikir dan bernalar seperti manusia. Tujuan dari kecerdasan buatan ini adalah membuat komputer lebih cerdas, mengerti tentang kecerdasan, dan membuat mesin lebih berguna bagi manusia. Kecerdasan buatan dapat membantu meringankan beban kerja manusia misalnya dalam membuat keputusan, mencari informasi secara lebih akurat, atau membuat komputer lebih mudah digunakan dengan tampilan yang mudah dipahami. Cara kerja kecerdasan buatan adalah menerima input, untuk kemudian diproses dan kemudian mengeluarkan output yang berupa suatu keputusan.

\section{Sistem Pakar}

Sistem pakar (expert system) adalah sistem yang berusaha mengadopsi pengetahuan manusia ke komputer yang dirancang untuk menyelesaikan masalah seperti layaknya seorang pakar.

Menurut Turban (2004), keahlian dipindahkan dari pakar ke suatu komputer. Pengetahuan ini kemudian disimpan di dalam komputer. Pada saat pengguna menjalankan komputer untuk mendapatkan informasi, sistem pakar menanyakan fakta-fakta dan dapat membuat penalaran (inferensi) dan sampai pada suatu kesimpulan. Kemudian, sistem pakar memberikan penjelasan (memberikan kesimpulan atas hasil konsultasi yang telah dilakukan sebelumnya).

\section{Pengertian Tanaman Kopi}

Kopi merupakan salah satu minuman yang paling terkenal di kalangan masyarakat. Kopi digemari karena memiliki citarasa dan aroma yang khas (Rahardjo, 2012). Kopi (Coffea sp) adalah spesies tanaman berbentuk pohon dan termasuk dalam famili Rubiaceae dan genus Coffea. 
Tanaman ini tumbuh tegak, bercabang dan dapat mencapai tinggi $12 \mathrm{~m}$. Tanaman kopi terdiri dari jenis Coffea arabica, Coffea robusta dan Coffea liberica (Yahmadi, 2007). Tanaman kopi merupakan komoditas ekspor yang mempunyai nilai ekonomis yang relatif tinggi di pasaran dunia, di samping merupakan salah satu komoditas unggulan yang dikembangkan di Indonesia.Sudah hampir tiga abad kopi diusahakan penanamannya di Indonesia untuk memenuhi kebutuhan konsumsi di dalam negeri dan luar negeri.

\section{METODE PENELITIAN}

\section{A. Tempat dan Waktu}

Penelitian ini akan dilaksanakan di Lab BTP (Budidaya Tanaman Perkebunan) sebagai tempat yang akan diteliti. Penelitian ini membutuhkan waktu selama 6 bulan yaitu bulan Oktober 2018 - Maret 2019 meliputi penyusunan proposal, pengambilan data, pembuatan aplikasi, dan penyusunan laporan.

\section{B. Alat dan Bahan}

Pengembangan sistem informasi ini menggunakan satu unit Laptop dengan spesifikasi sebagai berikut.

1. Spesifikasi hardware yang digunakan dalam pengembangan system ini adalah sebagai berikut:

a. Laptop Toshiba Satellite C800.

b. Processor Intel(R) Celeron(R) CPU B830@1.80GHz (2CPUs), $\quad 1.8 \mathrm{GHz}$.

\section{c. RAM 6 GB.}

d. HDD $320 \mathrm{~GB}$.

2. Spesifikasi softtware yang digunakan adalah sebagai berikut :
a. Sistem Operasi Windows 7 Ultimate.
b. XAMPP.
c. WEB PHP.

\section{Prosedur Peneitian}

1. Analisis Masalah

Melakukan Analisis pada suatu masalah merupakan tahap awal pada proses penelitian. Tahap ini dilakukan agar penelitian benar-benar dapat menemukan masalah ilmiah. Tahap ini dibangun berdasarkan rumusan masalah yang di dasari atas latar belakang masalah.

\section{Perancangan}

Pada tahap ini dilakukan perancangan sistem yang memerlukan suatu proses.

3. Pembuatan Aplikasi

Penjelasan pengerjaan sistem yang dilakukan adalah untuk membuat suatu aplikasi. Sistem pakar Penyakit Tanaman Kopi dengan web dengan menentukan faktafakta yang ditentukan oleh pakar.

\section{Testing}

Testing adalah kegiatan pengujian yang mengamati hasil eksekusi melalui data uji dan memeriksa fungsional dari perangkat lunak. Jadi mengevaluasi hanya dari tampilan luarnya (interface), fungsionalitasnya saja. Tanpa mengetahui apa sesungguhnya yang terjadi dalam proses detailnya (hanya mengetahui input dan output).

\section{Hasil Analisis}

Tahap ini hasil dari Metode Forward Chaining berbasis web yang dihasilkan suatu analisis yang merupakan hasil penelitian yang dilakukan.

Hasil atau pembuatan, pengujian, dapat dilihat pada Gambar 1 dibawah ini:

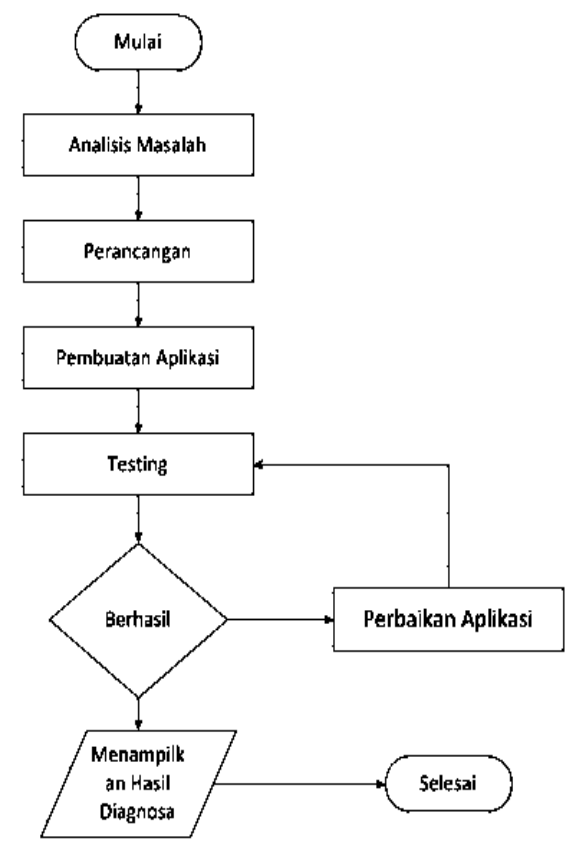

Gambar 1. Prosedur Penelitian

\section{Model Analisis}

Model representasi aliran proses perangkat lunak yanag akan dirancang akan disajikan dalam Context Diagram dan Data Flow Diagram (DFD). DFD digunakan untuk menggambarkan aliran informasi dan proses data yang bergerak dari input data hingga output. CD dan DFD memudahkan pemakai yang kurang menguasai bidang komputer untuk mengerti sistem yang akan dikerjakan atau dikembangkan.

\section{Data Flow Diagram (DFD)}

DFD terdiri dari satu proses, yaitu identifikasi fakta awal, proses identifikasi, gejala yang berkaitan dan proses penyimpulan. Pada gambar 2 DFD level 1 ada 7 proses untuk yang pertama proses login dari admin, yang kedua proses data penyakit, selanjutnya proses data gejala, data relasi dan data konsultasi user. Untuk proses user yang pertama yaitu proses daftar penyakit dan proses konsultasi, pada keseluruhan sistem serta 7 tabel yang terdapat dalam database yaitu tabel admin, tabel user, tabel penyakit, tabel gejala, tabel penyakit_gejala, tabel keterangan dan tabel hasil_konsultasi. 


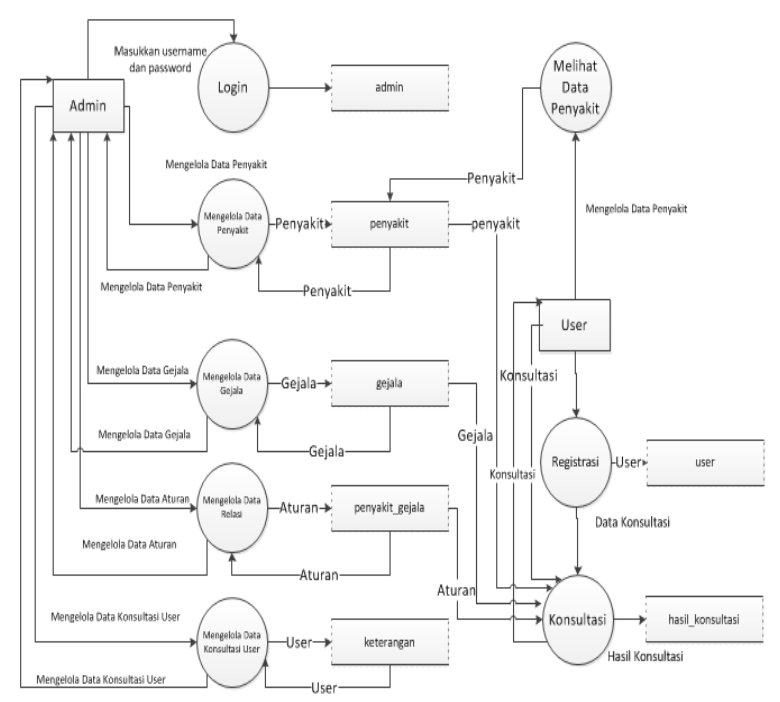

Gambar 2. DFD Level 1

\section{E. Perancangan Basis Data}

\section{ERD}

Pada Gambar 3 ERD sistem pakar penyakit tanaman kopi memiliki 4 entity relationship. Untuk proses awal user dapat melakukan konsultasi untuk mendapatkan hasil konsultasi, hasil konsultasi mengambil dari entity gejala dan dapat mendiagnosis penyakit.

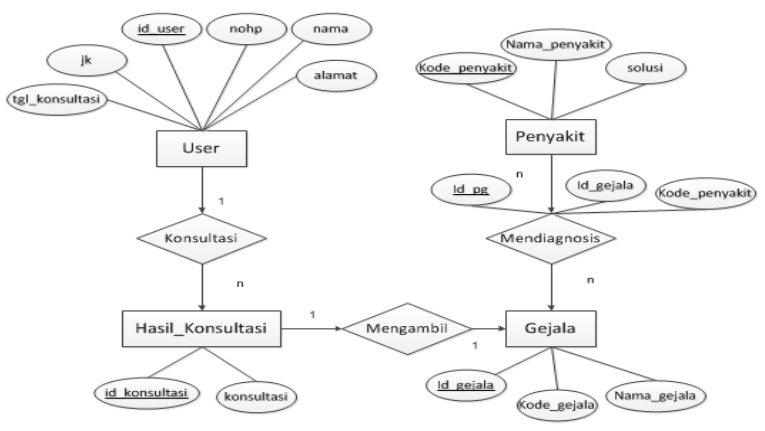

Gambar 3. ERD

\section{HASIL DAN PEMBAHASAN}

\section{A. Hasil}

User Interface merupakan tampilan dari aplikasi yang dibangun. Berikut beberapa interface yang terdapat dalam aplikasi, berikut tampilan halaman user dan admin

a. Tampilan halaman user terdiri dari :

1) Halaman utama

Tampilan halaman utama merupakan tampilan awal dari halaman user ketika user pertama kali memasuki aplikasi sistem pakar ini. Adapun tampilan halaman utama dapat dilihat pada gambar 4 .

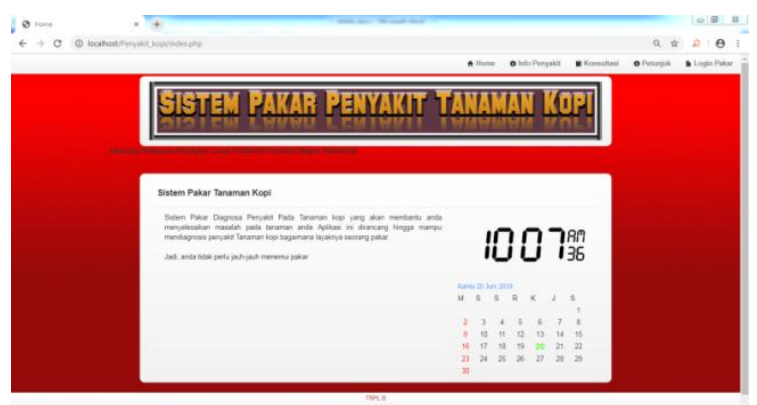

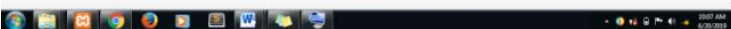

Gambar 4. Halaman User

2) Halaman konsultasi

Halaman konsultasi merupakan halaman yang menjadi pokok dari program karena dihalaman inilah user melakukan konsultasi sehingga user mengetahui gejala pada penyakit yang lebih cocok. Sebelum melakukan konsultasi, user atau pasien wajib melakukan registrasi terlebih dahulu untuk masuk ke halaman konsultasi. Berikut ini tampilan halaman registrasi dapat dilihat pada Gambar 5.

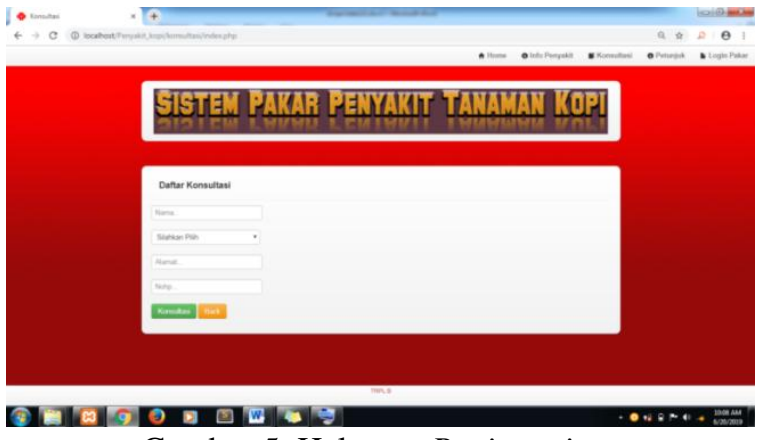

Gambar 5. Halaman Registrasi

Setelah user melakukan registrasi selanjutnya user dapat dialihkan ke halaman konsultasi sesuai yang telah terdaftar. Setelah itu user akan menandai gejala yang dialami pada tanaman kopi seperti pada Gambar 6.

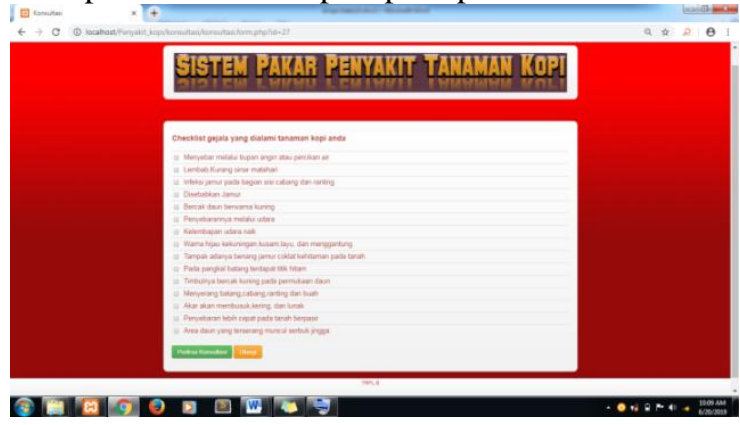

Gambar 6. Halaman Konsultasi

Pada halaman konsultasi, user yang sudah menandai gejala yang dipilih maka akan keluar hasil tampilan penyakit tanaman kopi seperti pada Gambar 7. 


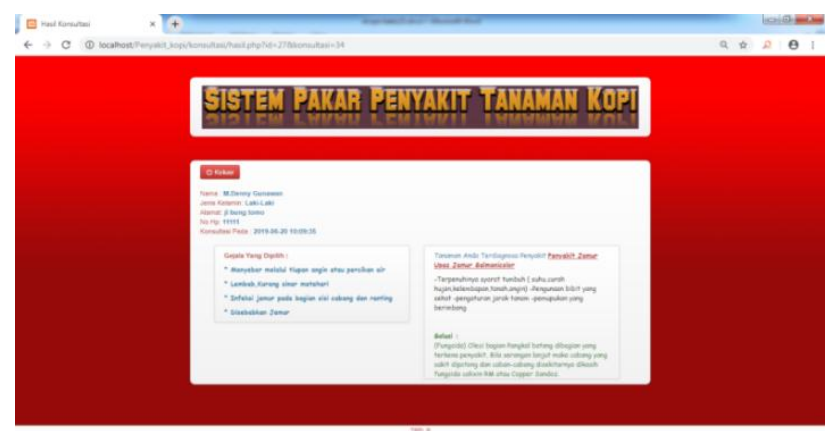

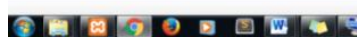

Gambar 7. Hasil Konsultasi

b. Tampilan halaman admin terdiri dari :

1) Halaman login pakar

Tampilan halaman login pakar, pakar dapat melakukan login dengan memasukkan username dan password yang udah terdaftar seperti pada Gambar 8 .

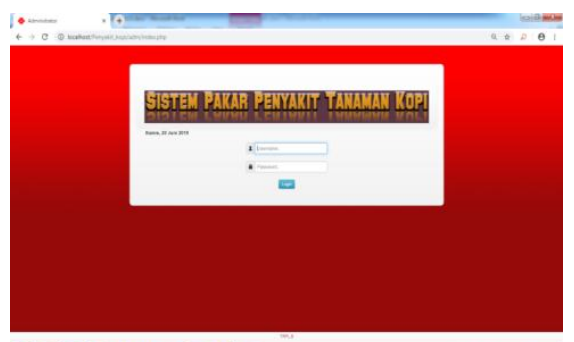

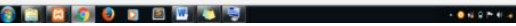

Gambar 8. Halaman Login Pakar

2) Halaman menu pakar

Tampilan halaman menu pakar berbeda dengan tampilan menu untuk user. Pada halaman menu pakar terdiri dari menu gejala, penyakit, infromasi dan hasil konsultasi user. Adapun tampilan menu pakar dapat dilihat pada Gambar 9.
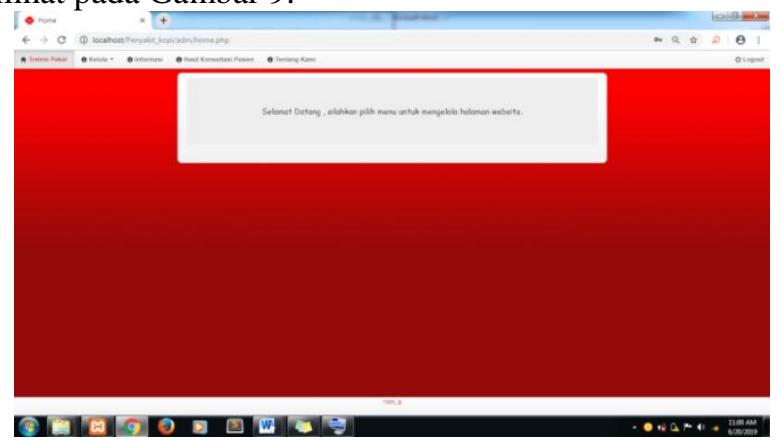

Gambar 9. Tampilan Menu Pakar

\section{3) Halaman menu gejala}

Tampilan halaman menu gejala pakar dapat mengubah data pada gejala, menambah data gejala dan menghapus data gejala dapat dilihat pada Gambar 10 .
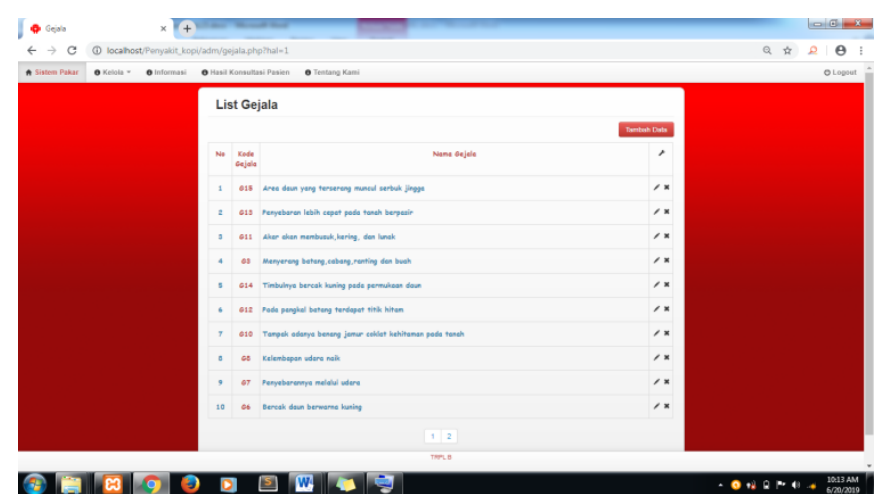

Gambar 10. Halaman Menu Gejala

4) Halaman menu penyakit

Tampilan halaman menu penyakit pakar dapat mengubah data pada penyakit, menambah data penyakit dan menghapus data penyakit dapat dilihat pada Gambar 11.

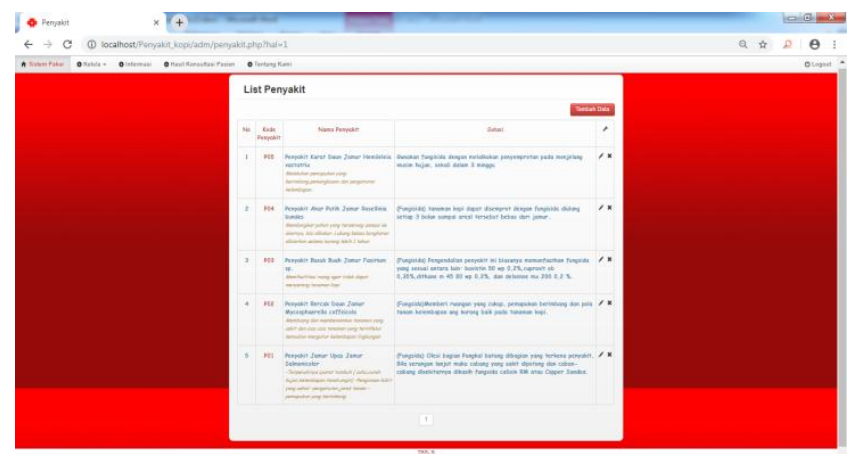

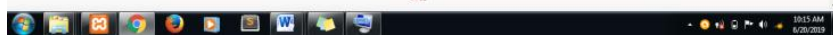

Gambar 11. Halaman Menu Penyakit

5) Halaman menu informasi

Tampilan halaman menu informasi pakar dapat mengisi data atau pembahasan tentang penyakit dan gejala, dan dapat ditampilkan maupun tidak ditampilkan di halaman informasi. Pakar dapat menambah data, mengubah data dan mengahapus data dapat dilihat pada Gambar 12.
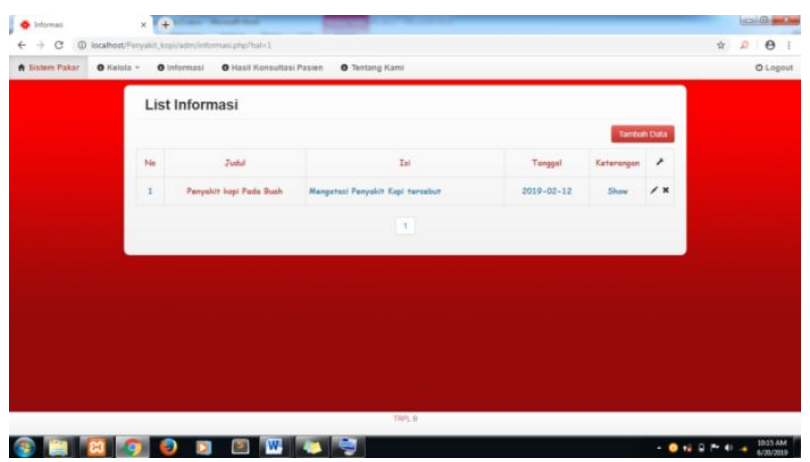

Gambar 12. Tampilan Menu Informasi

6) Halaman menu konsultasi user

Tampilan halaman menu konsultasi user pakar dapat melihat hasil konsultasi user yang didapat melalui halaman konsultasi dan hasil konsultasi, pakar cuman bisa menghapus data dapat dilihat pada Gambar 13. 


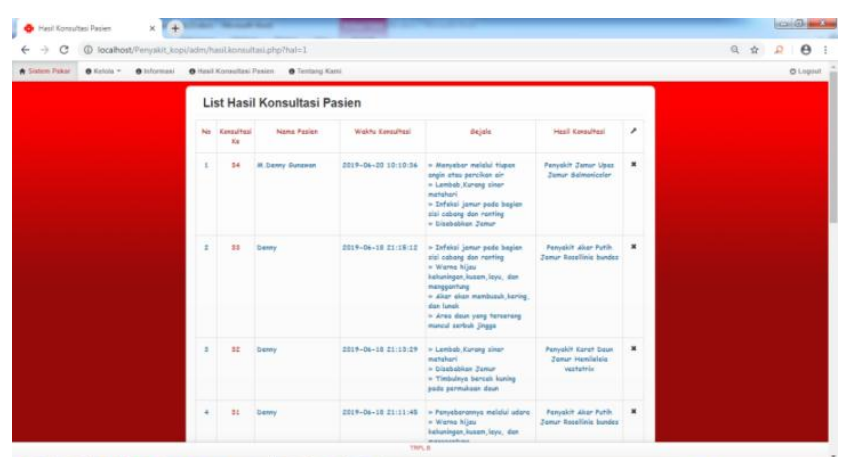

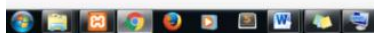

Gambar 13. Halaman Menu Konsultasi User

\section{B. Pengujian Tes Uji}

Pengujian validasi yang dilakukan oleh aplikasi dan juga pakar dengan gejala secara campuran dapat dilihat pada tabel 2.

Tabel 2. Pengujian Validasi

\begin{tabular}{|c|c|c|c|}
\hline \multirow{2}{*}{ Gejala } & \multirow{2}{*}{ Sistem } & Pakar & Validasi \\
\cline { 4 - 4 } & & & Valid \\
\hline G1,G2,G3,G8 & P01 & P01 & $\checkmark$ \\
\hline G5,G11,G13 & P04 & P04 & $\checkmark$ \\
\hline G2,G11,G12 & P04 & P04 & $\checkmark$ \\
\hline G2,G5,G9,G15 & P04 & P05 & $\times$ \\
\hline G4,G5,G11 & P04 & P04 & $\checkmark$ \\
\hline G5,G7,G8,G14 & P05 & P01 & $\times$ \\
\hline G2,G5,G6 & P02 & P02 & $\checkmark$ \\
\hline G3,G4,G8 & P03 & P03 & $\checkmark$ \\
\hline G1,G8,G10,G1 & P05 & P05 & $\checkmark$ \\
\hline 5 & P04 & P04 & $\checkmark$ \\
\hline G5,G11,G12 & & & \\
\hline
\end{tabular}

Berdasarkan tabel diatas telah dilakukan dengan 10 sampel data gejala pada tanaman kopi dan menghasilkan nilai akurasi sesuai perhitungan berikut:

Nilai Akurasi $=\sum$ match $/ \sum$ tp $* 100 \%$

Jadi nilai ke akurasi $=\frac{8}{10} * 100 \%=80 \%$

Jadi dapat disimpulkan bahwa akurasi sistem pakar berdasarkan 10 data yang diuji adalah $80 \%$ yang menunjukan bahwa sistem pakar ini berfungsi dengan baik sesuai dengan diagnosis pakar. Ketidakakurasian sistem pakar ini $20 \%$ yang disebabkan karena beberapa kemungkinan antara lain kesalahan dalam memberikan jawaban dalam diagnosis penyakit tanaman kopi.

\section{KESIMPULAN}

Aplikasi ini dapat memudahkan petani untuk mengetahui gejala dan penyakit pada tanaman kopi. Forward Chaining dapat dijadikan alternatif dalam melakukan hasil terhadap penentuan gejala dan penyakit tanaman kopi.

Diharapkan aplikasi sistem pakar ini dikembangkan menjadi aplikasi yang menggunakan framework dan aplikasi berbasis mobile sehingga fungsi dan kegunaannya dapat dipakai secara luas oleh banyak orang dimanapun dan kapanpun. Untuk Penelitian selanjutnya dapat dikembangkan lebih dari 5 penyakit pada tanaman kopi. Metodenya bisa menggunakan metode lain selain forward chaining.

\section{DAFTAR PUSTAKA}

Aksi Agraris, K. 2010. Bercocok Tanam Kopi, Yogyakarta.

Al Fatta, H. 2007. Analisis Perancangan Sistem Informasi, Andi, Yogyakarta.

Bambang, P. 2010. Budidaya dan Pasca Panen KOPI., Bogor: Pusat Penelitian dan Pengembangan Perkebunan.

Barnet, H. 1988. Inperfect Fungi. Bergess Publishing Company, Virginia Dinas Perkebunan Provinsi Jambi. 2012. Luas Dan Produksi Tanaman Perkebunan Menurut Jenis Tanaman. Jambi.

Dologite, D. G. 1993. Developing Knowledge-Based System Using VP-Expert, New York: Macmillan Publishing Company.

Kusrini. 2006. Sistem Pakar (Teori dan Aplikasi), Yogyakarta: Andi Offset.

Marimin. 2009. Teori dan Aplikasi Sistem Pakar dalam Teknologi Manajerial, Bogor: IPB Press.

Rahardjo, P. 2012. KOPI, Penebar Swadaya. Jakarta.

Setiarso, B. 2009. Teori Pengembangan dan ModelModel, Jakarta(ID): Organizational Knowledge Management Systems (OKMS).

Setiawan. 2013. Sistem Pakar Konsep dan Teori, Yogyakarta.

Sukamto, S. 1998. Pengelolaan Penyakit Tanaman Kopi. Kumpulan Materi Pelatihan dan Pengelolaan Organisme Pengganggu Tanaman Kopi, PUSLIT KOKA.

Turban. 2004. Decision Support System and Intellegent Systems Edisi Bahasa Indonesia jilid 1, Andi, Yogyakarta.

Yahmadi, M. 2007. Rangkaian Perkembangan dan Permasalahan Budidaya \& Pengolahan Kopi di Indonesia, Surabaya: Asosiasi Export Kopi Indonesia Jatim. 